\title{
Assessment of Influence of Designed Building on Insolation Conditions of Residential Development
}

\author{
Sergey Korniyenko \\ Institute of Architecture and Urban Planning Development \\ Volgograd State University of Architecture and Civil Engineering (VSUACE) \\ Volgograd, Russia \\ svkorn2009@yandex.ru
}

\begin{abstract}
Heat gain due to solar radiation through translucent elements of building envelope is an important component of building heat balance during heating period. The paper shows the necessity for taking into account the influence of designed buildings on the insolation conditions of the existing residential development. The placement of a designed building in the territory of the development reduces the heat gain due to solar radiation of the surrounding buildings, which increases heat consumption for heating.
\end{abstract}

Keywords - insolation, design methodology, insolation diagram, solar diagram, heat gain due to solar radiation, energy efficiency

\section{INTRODUCTION}

Heat gain due to solar radiation through translucent elements of building envelope is an important component of building heat balance during heating period. In the Russian design norms «Thermal protection of buildings» (SNiP 2302-2003 and SP 54.13330.2012) the calculation of the heat gain due to solar radiation is carried out with numerous simplifying assumptions. Thus, the building layout form is assumed to be rectangular. The shading of rooms caused by the elements of the building itself (window jambs, balconies and loggias, rizalite sections etc.) is not taken into account. The shading due to the presence of surrounding building is not taken into account either. There is no data for solar radiation in actual clouding conditions for many points of construction. While calculating the solar radiation value, the duration of the heating period is not taken into consideration. The influence of the designed building on the insolation conditions of the surrounding buildings is not taken into acount. The stated assumptions add a significant inaccuracy to the assessment of building energy efficiency.

Such scientists as N.M. Gusev, L.L. Dashkevich, B.A. Dunayev, N.V. Obolensky, D.V. Bakharev, I.S. Sukhanov, D.S. Maslennikov, B.F. Vasilyev, S.V. Szokolay, E.L. Harkness and M.L. Mehta have contributed a lot to the theory of insolation and solar control in architecture. At present, the insolation issues are also paid considerable attention to. The methods for calculating the residential and public buildings insolation are considered in paper [1].
Paper [2] analyzes the energy-oriented approach to the assessment of building insolation. In paper [3] the insolation assessment for the reconstruction of existing residential development was carried out. The method for calculating heat gain due to solar radiation for various durations of heating period is given in paper [4]. General issues of increasing the energy efficiency of buildings of various functional purposes are considered in papers [5-13].

The present paper gives the assessment of the influence of a designed building on the insolation conditions of residential development.

\section{Design Methodology}

The insolation conditions of residential development under reconstruction in Volgograd are the object of the investigation. The 12-storey public building is designed to be built in the territory of the residential development. The influence of the designed building on the insolation conditions of the residential development is studied.

General assessment of the insolation duration is carried out through the SANPiN (Sanitary regulations and Norms) method 2.2.1/2.1.1.1076-01 «Hygienic requirements to the insolation and solar control of rooms of residential and public buildings and territories». The calculation was carried out applying the insolation diagram developed by the author according to method [1] for the point of construction of the designed building ( $48^{\circ}$ north latitude). The insolation diagram was developed as applied to the days of spring and autumn equinox (March 22 and September 22). According to the method accepted the calculations of the insolation duration do not take into account the first hour after sunrise and the last hour prior to sunset. The inaccuracy of the method for calculating the insolation applying the insolation diagram does not exceed \pm 10 minutes.

By means of the insolation diagram application the residential buildings in the territory of the development were determined which get into the zone of influence of the designed building (Fig.1): four 9-storey residential buildings, one 3 -storey residential building and one 5-storey residential building. The building numbering is accepted as clockwise 
starting with the closest one to the designed building (marked with white color).

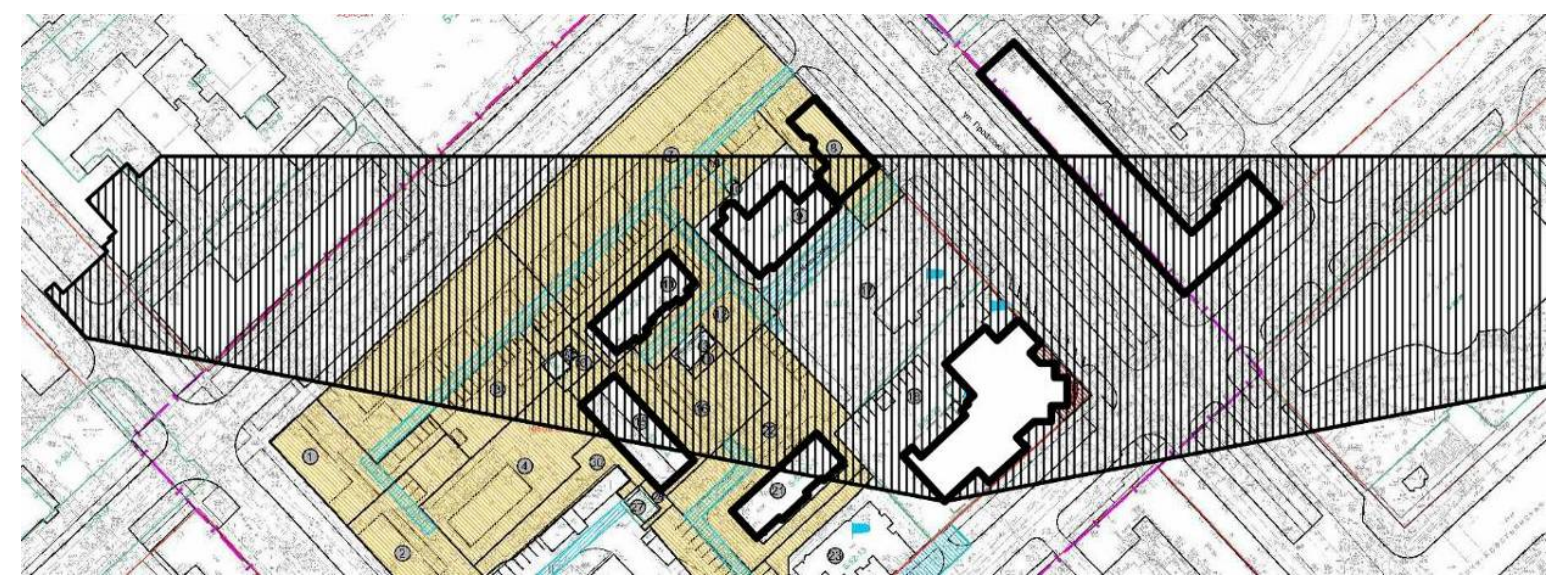

Figure 1. Scheme of determining the influence zone of designed building in the territory of residential development

The calculation of the insolation duration was carried out for all the residential rooms belonging to the influence zone of the designed building except for building 2 in which the insolation requirements had not been met even before the placement of the designed building. The insolation calculation was carried out for the design points of residential rooms determined with regard of the location and dimensions of the shading elements for those rooms. To determine the influence of the designed building on the insolation conditions of rooms, the calculation was carried out both prior to the placement of the designed building in the territory of the development and after the placement (Tab. $1)$.

TABLE I. DESIGN INSOLATION DURATION FOR RESIDENTIAL ROOMS OF BUILDINGS BELONGING TO THE DEVELOPMENTIN THE ZONE OF THE DESIGNED BUILDING INFLUENCE

\begin{tabular}{|c|c|c|c|c|c|}
\hline \multirow[b]{2}{*}{$\begin{array}{l}\text { Building } \\
\text { number }\end{array}$} & \multirow{2}{*}{$\begin{array}{l}\text { Storey / Flat } \\
\text { number } \\
\text { (according } \\
\text { to Technical } \\
\text { passport) }\end{array}$} & \multirow[b]{2}{*}{$\begin{array}{l}\text { Number of } \\
\text { residential } \\
\text { rooms in } \\
\text { the flat }\end{array}$} & \multirow[b]{2}{*}{$\begin{array}{c}\text { Number / Square } \\
\text { of residential } \\
\text { room under } \\
\text { study }\end{array}$} & \multicolumn{2}{|c|}{ Design insolation duration } \\
\hline & & & & $\begin{array}{c}\text { prior to the placement } \\
\text { of the designed } \\
\text { building }\end{array}$ & $\begin{array}{c}\text { after the placement } \\
\text { of the designed } \\
\text { building }\end{array}$ \\
\hline \multirow{2}{*}{1} & $1 / 1$ & 2 & $7 / 18.5$ & $6 \mathrm{~h} 10 \mathrm{~min}$ & $5 \mathrm{~h} 35 \mathrm{~min}$ \\
\hline & $1 / 2$ & 1 & $2 / 18.6$ & $6 \mathrm{~h} 00 \mathrm{~min}$ & $5 \mathrm{~h} 45 \mathrm{~min}$ \\
\hline \multirow{4}{*}{3} & $1 / 1$ & 2 & $5 / 14.7$ & $2 \mathrm{~h} 45 \mathrm{~min}$ & $1 \mathrm{~h} 50 \mathrm{~min}$ \\
\hline & $1 / 3$ & 3 & $5 / 18.6$ & $4 \mathrm{~h} 45 \mathrm{~min}$ & $3 \mathrm{~h} 15 \mathrm{~min}$ \\
\hline & $1 / 28$ & 2 & $5 / 14.6$ & $5 \mathrm{~h} 00 \mathrm{~min}$ & $3 \mathrm{~h} 25 \mathrm{~min}$ \\
\hline & $1 / 30$ & 3 & $5 / 18.6$ & $6 \mathrm{~h} 15 \mathrm{~min}$ & $4 \mathrm{~h} 25 \mathrm{~min}$ \\
\hline \multirow{5}{*}{4} & \multirow{2}{*}{$2 / 1$} & \multirow{2}{*}{3} & $6 / 16.6$ & $6 \mathrm{~h} 45 \mathrm{~min}$ & $5 \mathrm{~h} 15 \mathrm{~min}$ \\
\hline & & & $7 / 14.6$ & $6 \mathrm{~h} 20 \mathrm{~min}$ & $4 \mathrm{~h} 45 \mathrm{~min}$ \\
\hline & $2 / 2$ & 1 & $2 / 23.0$ & $4 \mathrm{~h} 30 \mathrm{~min}$ & $4 \mathrm{~h} 00 \mathrm{~min}$ \\
\hline & \multirow{2}{*}{$2 / 3$} & \multirow{2}{*}{2} & $5 / 24.7$ & $6 \mathrm{~h} 55 \mathrm{~min}$ & $4 \mathrm{~h} 50 \mathrm{~min}$ \\
\hline & & & $6 / 15.5$ & $6 \mathrm{~h} 35 \mathrm{~min}$ & $4 \mathrm{~h} 25 \mathrm{~min}$ \\
\hline \multirow{3}{*}{5} & $2 / 9$ & 3 & $3 / 11.2$ & $7 \mathrm{~h} 10 \mathrm{~min}$ & $6 \mathrm{~h} 40 \mathrm{~min}$ \\
\hline & \multirow{2}{*}{$2 / 10$} & \multirow{2}{*}{2} & $1 / 12.6$ & $6 \mathrm{~h} 40 \mathrm{~min}$ & $5 \mathrm{~h} 30 \mathrm{~min}$ \\
\hline & & & $2 / 10.0$ & $6 \mathrm{~h} 50 \mathrm{~min}$ & $5 \mathrm{~h} 30 \mathrm{~min}$ \\
\hline \multirow{12}{*}{6} & \multirow{2}{*}{$2 / 19$} & \multirow{2}{*}{2} & $5 / 14.4$ & $6 \mathrm{~h} 45 \mathrm{~min}$ & $3 \mathrm{~h} 55 \mathrm{~min}$ \\
\hline & & & $6 / 15.1$ & $6 \mathrm{~h} 35 \mathrm{~min}$ & $3 \mathrm{~h} 45 \mathrm{~min}$ \\
\hline & \multirow{2}{*}{$2 / 20$} & \multirow{2}{*}{2} & $2 / 13.6$ & $6 \mathrm{~h} 25 \mathrm{~min}$ & $3 \mathrm{~h} 40 \mathrm{~min}$ \\
\hline & & & $3 / 18.2$ & $6 \mathrm{~h} 45 \mathrm{~min}$ & $4 \mathrm{~h} 00 \mathrm{~min}$ \\
\hline & $2 / 21$ & 3 & $2 / 15.9$ & $6 \mathrm{~h} 50 \mathrm{~min}$ & $4 \mathrm{~h} 25 \mathrm{~min}$ \\
\hline & $2 / 36$ & 3 & $7 / 15.6$ & $6 \mathrm{~h} 25 \mathrm{~min}$ & $3 \mathrm{~h} 50 \mathrm{~min}$ \\
\hline & \multirow{2}{*}{$2 / 37$} & \multirow{2}{*}{2} & $5 / 18.2$ & $6 \mathrm{~h} 20 \mathrm{~min}$ & $3 \mathrm{~h} 55 \mathrm{~min}$ \\
\hline & & & $6 / 13.8$ & $6 \mathrm{~h} 10 \mathrm{~min}$ & $3 \mathrm{~h} 55 \mathrm{~min}$ \\
\hline & $2 / 38$ & 1 & $2 / 17.5$ & $5 \mathrm{~h} 55 \mathrm{~min}$ & $3 \mathrm{~h} 35 \mathrm{~min}$ \\
\hline & $2 / 39$ & 3 & $2 / 15.8$ & $5 \mathrm{~h} 45 \mathrm{~min}$ & $3 \mathrm{~h} 45 \mathrm{~min}$ \\
\hline & $2 / 56$ & 3 & $7 / 13.0$ & $5 \mathrm{~h} 40 \mathrm{~min}$ & $3 \mathrm{~h} 50 \mathrm{~min}$ \\
\hline & $2 / 57$ & 2 & $5 / 17.9$ & $5 \mathrm{~h} 25 \mathrm{~min}$ & $3 \mathrm{~h} 35 \mathrm{~min}$ \\
\hline
\end{tabular}


Tab. 1 shows that prior to the placement of the designed building in the development territory the insolation duration varies from $2 \mathrm{~h} 45 \mathrm{~min}$ to $7 \mathrm{~h} 10 \mathrm{~min}$. The placement of the designed building in the territory of the development reduces the insolation duration in all the rooms studied. The minimum insolation duration amounts to $1 \mathrm{~h} 50 \mathrm{~min}$ (building 3, flat 1 , residential room 5). Therefore the given room falls within the "risk" zone.

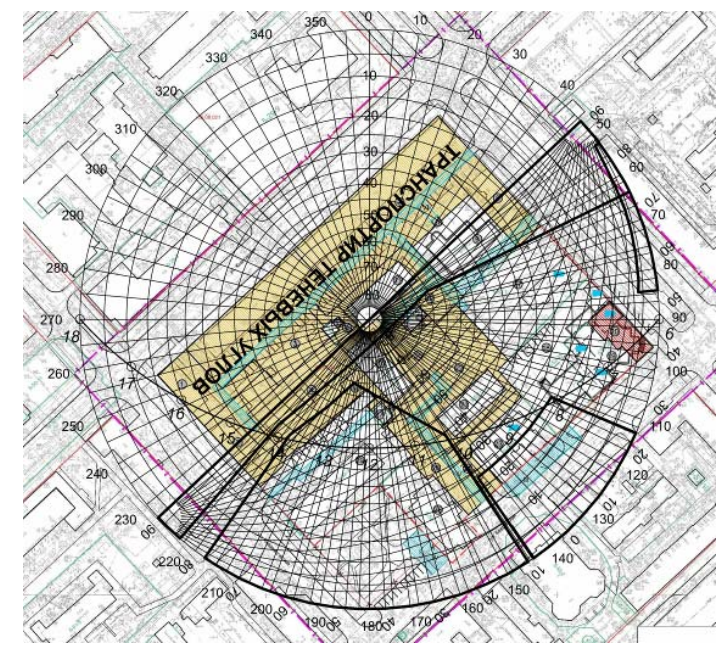

To verify the obtained results the calculation of insolation duration in the "risk" room was carried out applying solar diagram. The solar diagram was developed by the author in accordance with method [1] on the basis of sky stereographic projection for the point of construction of the designed building as applied to the days of spring and autumns equinox. The results of the calculation of insolation duration with use of solar diagram for "risk" room are given in Fig. 2.

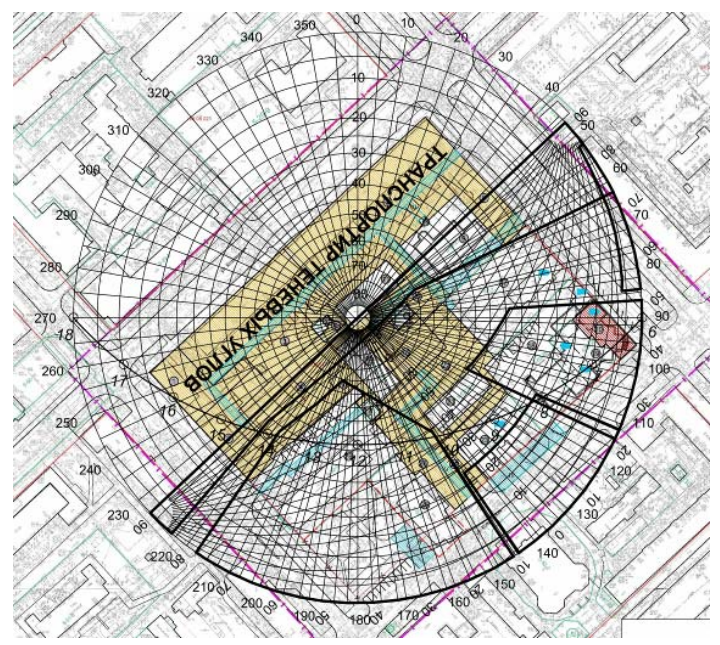

Figure 2. Schemes of determining the insolation duration applying the solar diagram for "risk" room prior to the placement of the designed building in the territory of residential development (left) and after the placement (right)

The analysis of the results shows that prior to the placement of the designed building in the territory of the development the insolation duration in the "risk" room amounts to $3 \mathrm{~h} 10 \mathrm{~min}$ within the period between 7:00 and 10:10. After the placement of the designed building the insolation duration equals $2 \mathrm{~h} 00 \mathrm{~min}$ within the period between $8: 10$ and 10:10, which meets the normative requirements. The calculation applying solar diagrams allows determining more precisely not only the insolation duration but also the structure of room shading caused by the shading elements of the building itself as well as by the opposing buildings of the development (Tab. 2).

TABLE II. STRUCTURE OF "RISK” ROOM SHADING

\begin{tabular}{|l|c|c|}
\hline \multirow{2}{*}{ Shading element } & \multicolumn{2}{c|}{ Share of shading [\%] } \\
\cline { 2 - 3 } & $\begin{array}{c}\text { prior to the placement of the } \\
\text { designed building }\end{array}$ & $\begin{array}{c}\text { after the placement of the } \\
\text { designed building }\end{array}$ \\
\hline Building 1 & 10.4 & 10.4 \\
\hline Building 2 & 33.9 & 33.9 \\
\hline Building 3 (window jambs of the "risk" room) & 14.4 & 14.4 \\
\hline Building 4 & - & - \\
\hline Building 5 & - & - \\
\hline Building 6 & 1.48 & 1.48 \\
\hline Designed building & - & 12.4 \\
\hline
\end{tabular}

The share of shading with a building element is determined as the ratio of the square of the projection of sky section shaded by the given element to the total square of non-shaded sky projection (as a percentage). The analysis of the results demonstrates that building 2 has the maximum element-wise shading of "risk" room (33.9 \%). The total shading of "risk" room prior to the placement of the designed building equals $60.1 \%$, after the placement it equals $72.5 \%$.
The assessment of the design building influence on the heat gain due to solar radiation of a "risk" room was carried out for the following initial data. The "risk" room has a wall aperture filled with a window unit of one-chamber glasses in PVC window profiles. According to the reference data the total coefficient of solar radiation transmittance amounts to 0.43 . The geographic latitude of the territory $\varphi=48^{\circ}$. The window is oriented to South-East (S-E). The calculation was 
carried out for the day of spring equinox on the basis of the insolation duration data obtained by means of the solar diagram (Tab. 3).

The results of the calculation shows (see Tab. 3) that the placement of the designed building in the territory of the development causes $26.6 \%$ reduction of the heat gain due to solar radiation in the "risk" room. Thus, infill construction negatively influences the performance parameters of surrounding buildings increasing heat consumption for heating.

TABLE III. RESULTS OF CALCULATION

\begin{tabular}{|c|c|c|}
\hline \multirow[b]{2}{*}{ Index } & \multicolumn{2}{|c|}{ Index value $\left[\mathrm{MJ} /\left(\mathrm{m}^{2} \cdot\right.\right.$ day $\left.)\right]$} \\
\hline & $\begin{array}{l}\text { prior to the placement of } \\
\text { the designed building }\end{array}$ & $\begin{array}{c}\text { after the placement of the } \\
\text { designed building }\end{array}$ \\
\hline Direct solar radiation & 1.98 & 1.45 \\
\hline Scattered solar radiation & 0.71 & 0.52 \\
\hline Total solar radiation & 2.69 & 1.97 \\
\hline Specific heat gain due to solar radiation & 1.16 & 0.85 \\
\hline
\end{tabular}

\section{SUMMARY}

The investigations carried out by the author demonstrate the necessity for taking into account the influence of designed buildings on the insolation conditions of existing residential development. The placement of a designed building in the territory of the development reduces the heat gain due to solar radiation of the surrounding buildings in the development and increases heat consumption for heating.

\section{ACKNOWLEDGMENT}

The author expresses his deep gratitude to N.I. Vatin, Doctor of Engineering, Professor of National Research University "St.Petersburg State Polytechnical University" for valuable commentaries made in the process of work over the paper manuscript.

\section{REFERENCES}

[1] V.A. Zemtsov and V.G. Gagarin, "Insolation of residential and public buildings. Development prospects," Academia. Architecture and Construction, vol. 5, 2009, pp. 147-151.

[2] V.N. Kupriyanov and F.R. Khalikova, "New Proposals for Standardization and Calculation of Insolation of Living Spaces," Housing Construction, vol. 6, 2013, pp. 50-53.

[3] S.V. Korniyenko, "Assessment of insolation of residential buildings in a zone of influence of the designed building," Bulletin of Volgograd State University of Architecture and Civil Engineering. Series: Civil Engineering and Architecture, vol. 27 (46), 2012, pp. $156-163$.
[4] S.V. Korniyenko, "Calculation of heat gain to solar radiation for an assessment of energy efficiency of buildings," Light and Engineering, vol. 2, 2013, pp. 64-65.

[5] N.I. Vatin, D.V. Nemova, D.S. Tarasova and A.A. Staritcyna, "Increase of Energy Efficiency for Educational Institution Building," Advanced Material Research, vol. 953-954, 2014, pp. 854-870.

[6] N.I. Vatin, D.V. Nemova, A.S. Kazimirova and K.N.Gureev, "Increase of Energy Efficiency of the Building of Kindergarten", Advanced Material Research, vol. 953-954, 2014, pp. 1537-1544.

[7] S.V. Korniyenko, "Design and experimental control of buildings energy saving," Magazine of Civil Engineering, vol. 8 (43), 2013, pp. 24-30.

[8] S.V. Korniyenko, "The experimental analysis and calculative assessment of building energy efficiency," Applied Mechanics and Materials, vol. 618, 2014, pp. 509-513.

[9] N.I. Vatin, D.V. Nemova, P.P. Rymkevich and A.S. Gorshkov, "Influence of building envelope thermal protection on heat loss value in the building," Magazine of Civil Engineering, vol. 8, 2012, pp. 414.

[10] V. Motuzienè, K. Valančius and G. Rynkun, "Complex analysis of energy efficiency of public buildings: case study of VGTU," Magazine of Civil Engineering, vol. 2, 2012, pp. 9-17.

[11] H. Sozer, "Improving energy efficiency through the design of the building envelope," Building and Environment, vol. 45, 2010, pp. 2581-2593.

[12] A. Roetzel, A. Tsangrassoulis and U. Dietrich, "Impact of building design and occupancy on office comfort and energy performance in different climates," Building and Environment, vol. 71, 2014, pp. $165-175$.

[13] S. Korniyenko, "Thermal comfort and energy performance assessment for residential building in temperate continental climate," Applied Mechanics and Materials, vol. 725-726, 2015, pp. 13751380 . 